\title{
Goodwill Impairment: A New Window For Earnings Management?
}

Yousef Jahmani, Savannah State University, USA

William A. Dowling, Savannah State University, USA

Paul D. Torres, Savannah State University, USA

\begin{abstract}
The Financial Accounting Standards Board promulgated standard No. 142 in an attempt to improve the understandability of accounting information. This new rule eliminated the practice of automatically amortizing goodwill. No. 142 requires public companies to test goodwill for possible impairment at least annually. An unintended consequence of this new standard is the opportunity for companies to use it in earnings management. To test the possibility that the rule is being used for this purpose, a sample of companies was chosen, all of which had amounts of goodwill on their balance sheet during the 2003-2005 interval. The results reveal that the number of companies experiencing losses or low rates of return on total assets who actually impaired goodwill was statistically insignificant during the period under consideration. Thus, the results strongly suggest that companies are using No. 142 in an attempt to manage the volatility of earnings.
\end{abstract}

\section{INTRODUCTION}

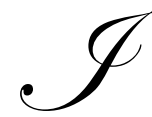
n July 2001, the Financial Accounting Standards Board (FASB) issued Statement of Financial Accounting Standards (SFAS) Number 141 and SFAS No. 142. These statements concerned the accounting for business combinations and the treatment of goodwill and other intangible assets on a company's financial statements. (SFAS) No. 141 eliminated the pooling of interests method of accounting for a business combination. Specifically, all acquisitions initiated after July 2001 were to be accounted for as purchase arrangements and, therefore, might require a partial allocation of the purchase price to goodwill. Little guidance was provided as to the determination of and measurement of goodwill impairment. Users of financial statements as well as management expressed dissatisfaction with the statement, as intangible assets were an increasingly important economic resource for many companies and represented an important portion of the assets acquired. Better information was needed about these resources.

(SFAS) No. 142 supersedes APB No. 17's treatment of intangible assets, which required the amortization of goodwill over a period not to exceed forty years. (SFAS) No. 142 was to provide guidance on how intangible assets that were acquired individually or with a group of other assets should be accounted for upon their acquisition. It addressed how goodwill and other intangible assets should be accounted for after they were recognized in the financial statements. The new standard required that goodwill be tested annually for possible impairment. Since goodwill was no longer annually amortized, the reported amount of goodwill would not decrease in a systematic manner. Consequently, reported net income may well be more volatile than before, as impairment losses are likely to be irregular and in varying amounts. Managements, for different reasons, do not appreciate or desire volatility in earnings. Thus, they might choose a convenient time to recognize impairment losses such that the recognition allows a smoothing of earnings. Previous research on goodwill impairment and earning management focused mainly on the year of SFAS No. 142 implementation. This paper expands the window for focusing on goodwill impairment to include the period after the year it was adopted.

The objective of this paper is to test whether management deliberately selects the timing of goodwill impairment recognition as a means to smooth the company's earnings. The remainder of the paper is organized as follows: Section 2 outlines the accounting for goodwill followed by Section 3, which provides the theoretical 
background and develops our hypotheses. Section 4 describes the data selection and methodology, while Section 5 focuses on analyses of findings and their implications. Lastly, Section 6 concludes the paper.

\section{Accounting for Goodwill}

Goodwill has long been a controversial subject. Wines and Ferguson (1993) and McCarthy and Schneider (1995) documented the fact that the controversy regarding the accounting for goodwill in US and abroad had existed since the early 1900s. The controversy focused on the recognition of goodwill as an asset, on its treatment and its link to the income statement. A search of the accounting literature yields two definitions of goodwill. One is that goodwill is the excess of purchase price over fair value of the net assets acquired. Alternatively, goodwill is defined as the price paid for excess earnings where excess earnings are defined as the difference between the earnings of the acquired asset over the normal earnings for a similar business. The later definition clearly links goodwill to earnings.

Historically, there are three views on the treatment of goodwill. The first suggests that goodwill should be written off immediately against retained earnings. The second view holds that goodwill is a wasting asset and it should be amortized over a useful life. Further, the amount of goodwill amortized should be allocated to periods where it contributes to company's earnings. The Accounting Principles Board (APB) Opinion No.17 was based on this view as it required companies to amortize goodwill over a period not exceeding forty years using straight-line method. The third view holds that goodwill held due to an acquisition was to be capitalized indefinitely and tested periodically for possible impairment. Goodwill that was internally generated should be expensed immediately.

Under SFAS No 142, goodwill impairment is determined using a two-step process. The first step of the goodwill impairment test is designed to identify potential impairment by comparing the fair market value of a reporting unit (generally, reportable segments) with its net book value (or carrying amount), including goodwill. If the fair value of a reporting unit exceeds its carrying amount, goodwill of the reporting unit is considered not impaired and the second step of the impairment test is unnecessary. If the reverse is true and the carrying amount of a reporting unit exceeds its fair value then the second step of the goodwill impairment test is performed. The second step of the goodwill impairment test is designed to measure the amount of impairment loss, if any. The second step compares the implied fair value of the reporting unit's goodwill with the carrying amount of that goodwill. If the carrying amount of the reporting unit's goodwill exceeds the implied fair value of that goodwill, an impairment loss is recognized in an amount equal to that excess. The implied fair value of goodwill is determined in the same manner as the amount of goodwill recognized in a business combination. That is, the fair value of the reporting unit is allocated to all of the assets and liabilities of that unit (including any unrecognized intangible assets) as if the reporting unit had been acquired in a business combination and the fair value of the reporting unit was the purchase price paid to acquire the reporting unit. However, the issuance of this new standard on goodwill does not diminish disagreement over goodwill. The application of SFAS No. 142 requires estimates and judgment of many aspects and these may open the door for manipulation.

\section{Theoretical Framework and Hypothesis Development}

In rationalizing the issuance of SAFS No.142, FASB concluded that the traditional straight-line amortization of goodwill was not consistent with the concept of representational faithfulness. The Board also concluded that non-amortization of goodwill coupled with the impairment testing was consistent with that concept. When applying the statement, the Board recommended that companies utilize cash flow information and the determination of present value in estimating fair value in testing both goodwill and other intangible assets that are subject to impairment.

The determination of the fair value of a reporting unit in the first step of the goodwill impairment test and determination of the fair value of individual assets and liabilities of a reporting unit (including unrecognized intangible assets) in the second step of the goodwill impairment test is judgmental in nature. Thus, such determination will often involve the significant use of estimates and assumptions. Similarly, estimates and assumptions are used in determining the fair value of other intangible assets. These estimates and assumptions could have a significant impact not only on whether an impairment charge is recognized but also on the magnitude 
of any such charge. To assist in determining whether goodwill impairment is present, companies may obtain appraisals from independent valuation firms. Additionally, some companies perform internal valuation analyses and consider other publically available market information. Estimates of fair value are primarily determined using discounted cash flows and market comparisons. These approaches use significant estimates and assumptions including projected future cash flows, their timing, discount rates reflecting the risk inherent in future cash flows, perpetual growth rates, the determination of appropriate market comparables, and the determination of whether a premium or discount should be applied to comparables. Clearly, considerable management judgment is necessary to estimate the fair value of reporting units. The estimated fair value may also be impacted by future actions undertaken by management and competitors as well being impacted by the economic environment in which they operate. Estimates formed under these caveats can significantly affect the balance of goodwill and intangible assets on consolidated balance sheets and on consolidated statements of operations.

The use of managerial judgment and estimates may lower earning quality and the use of estimates and judgments in the determination of fair value, cash flow, and discount rates provides potential opportunities for earnings management. Management's motivation to do so includes greed (maximization of compensation), promotion, job security, the maximization of share price, the minimization of the probability of bankruptcy, the avoidance of violating restrictive debt covenants, and/or the minimization of regulatory intervention (McKee, 2005).

There are other indicators for goodwill impairment. For example, a significant change in the business climate may cause companies to sustain losses for more than one year suggesting that goodwill should be impaired. Goodwill impairment will exacerbate their losses. With the new rules, companies may reduce their losses by not recognizing goodwill impairment and postponing it to later years when they are experiencing high returns. Thus:

H1: Companies that incur losses for three consecutive years tend to avoid goodwill impairment.

Again, significant changes in business climate, among other reasons, may cause companies to experience a decline in the return on assets ratio (ROA) for two or more years suggesting that goodwill should be impaired. If companies impair their goodwill, it will exacerbate the decrease in ROA or perhaps even incur losses. Therefore, companies may defer impairment losses to later years when ROA is high enough to withstand the reduction. Therefore:

H2: Companies that experience a low ROA for three consecutive years tend to avoid goodwill impairment.

\section{THE SAMPLE}

The population includes all companies with goodwill on their balance sheet for the years 2003-2005 where the financial information is available from public sources. A sample of 200 companies was randomly selected from different sectors. Twenty nine of the selected companies have goodwill on their balance sheet but the financial information about goodwill is unclear and lacking. The annual financial reports for the remaining companies were requested from the annualreportservice.com for the year 2005 and from each company's headquarters for the years 2003 and 2004. Fifty six (56) either did not reply or sent only one year's annual report or sent annual reports that did not contain financial statements. The remaining companies (117) formed the test sample. The annual reports were utilized to obtain net income, amount of goodwill, total assets and impairment losses for the years 2003-2005. Table I classifies these companies according to their industrial sector.

Table I: Sector Classification of the Sample

\begin{tabular}{|ccccc|}
\hline Sector & Basic Materials & Consumer Goods & Financial & Health Care \\
\# of Firms & 2 & 7 & 4 & 36 \\
\hline Sector & Services & Technology & Utilities & Industrial goods \\
\# of Firms & 27 & 12 & 0 & 29 \\
\hline
\end{tabular}




\section{STUDY FINDINGS}

\section{Losses Factor}

SFAS No. 142 requires that goodwill impairment testing be performed annually. Additionally, it provides lists of events and circumstances whose occurrence mandates the testing of reporting units for impairment between annual tests. Included in the list is the circumstance where the reporting unit has a current period operating loss or cash flow loss combined with a history of operating losses or cash flow losses or a forecast of continuing losses. The assumption here is that if a company experience losses for a period of time, it should recognize a goodwill impairment loss.

Table II: Companies Reporting Losses for One or Two or Three Years

\begin{tabular}{|c|c|c|c|}
\hline Sample Size & $\begin{array}{c}\text { \# incurring } \\
\text { losses for 3 years }\end{array}$ & $\begin{array}{c}\text { \# incurring } \\
\text { losses for 2 years }\end{array}$ & $\begin{array}{c}\text { \# incurring } \\
\text { losses for 1 year }\end{array}$ \\
\hline Total =117 & 24 & 13 & 11 \\
\# with impaired goodwill & 10 & 1 & 4 \\
\hline Percentage & 41.6 & 7.7 & 36.6 \\
\hline
\end{tabular}

Table II presents summary statistics showing the number of companies incurring losses for three years or less. Twenty-four companies in the sample incurred losses for the entire period under consideration (2003-2005). Of this number, ten companies impaired their goodwill during the period. Further, of this ten, nine impaired their goodwill once and one impaired goodwill twice during this period. Further examination of the three year period reveals that three impaired goodwill in the first year, three in the second year, and five in the third year. Clearly, these results suggest that companies did not choose to impair their goodwill. One obvious reason is immediately apparent. It could well be that these companies were attempting to avoid exacerbating current losses by postponing goodwill impairment for years when earnings were higher. Thus, the hypothesis that companies incurring losses for three consecutive years tend to avoid goodwill impairment is accepted

The third column in table II shows the number of companies that incurred losses for two of the three years under consideration. Thirteen companies experienced such losses and only one (7.7\%) impaired goodwill. This result reinforces the previous findings. Perhaps these companies also postponed goodwill impairment to later years when returns would hopefully be more positive. For those eleven companies that incurred losses for only one year, column four shows that four (36.6\%) impaired their goodwill. When their return on assets for the other two years was scrutinized it was found that it either declined or was less than two percent.

Collectively, the number of companies incurring a loss or losses for at least one year was forty-eight. Of this number, only fifteen (31.1\%) impaired their goodwill. This suggests that most of these companies were attempting to manage the volatility of earnings by avoiding taking impairment losses in the period studied as to avoid exacerbating the losses.

\section{A Market Capitalization Decline}

One of SFAS No. 142's requirements is that goodwill impairment tests are to be carried out when a decline in the market capitalization of an entity (or a reporting unit) below the carrying amount of its net assets is other than temporary. One accounting measure that indicates a decline in the market capitalization is the return on assets. If a company experiences a low return on assets for one year or more, it is assumed that the firm's market value declined. We assumed that $2 \%$ level for ROA to be low for the firms in the sample. Therefore, it will be used as a criteria or indication of a decline in the market capitalization. 
Table III: Companies Experiencing 2\% Or Less Return On Assets During The Study Period

\begin{tabular}{|c|c|c|c|}
\hline \# In The Sample & $\begin{array}{c}\text { \# with ROA 2\% or less for } \\
\text { 3 consecutive years }\end{array}$ & $\begin{array}{c}\text { \# with ROA 2\% or less for } \\
\text { 2 of the three years }\end{array}$ & $\begin{array}{c}\text { \# with ROA 2\% or less for } \\
\text { 1 of the three years }\end{array}$ \\
\hline 117 & 35 & 12 & 7 \\
\cline { 1 - 1 } \# that impaired goodwill & 11 & 0 & 1 \\
Percentage & 31.4 & 0 & 14.2 \\
\hline
\end{tabular}

Table III shows the number of companies that earned a return on assets of $2 \%$ or less for 3 consecutive years, for 2 years, and for one year. Thirty-five companies earned less than two percent on assets for three successive years and of this number, eleven impaired their goodwill. Note that for all thirty-five firms, return on assets was less than or equal to two percent, suggesting that it is likely that goodwill was impaired for all of them. Similarly, firms with low returns on assets for two years were likely to have impaired capital but none of them impaired their goodwill during the period under study. These results suggest that these companies postponed (managing their earnings) reducing goodwill to later periods when earnings were anticipated to be higher. Thus the hypothesis that firms with low returns on assets for three consecutive years tend to avoid goodwill impairment is accepted.

\section{SUMMARY AND CONCLUSION}

The Financial Accounting Standards Board issued Statement of Financial Accounting Standards Number 142 that eliminated traditional straight-line amortization of goodwill. Instead, it required that goodwill be tested at least annually and should specific events and circumstances occur, it required additional testing. Testing requires judgments, estimation, and that certain assumptions be made which collectively may provide leeway for management to manipulate earnings. In the research chronicled here, return on assets was utilized as the indicator for possible goodwill impairment. The evidence shows that the majority of companies posting losses for three consecutive years and the majority of those firms posting losses for two years did not impair their goodwill. Additionally, there is convincing evidence that the majority of firms earning returns on assets of two percent or less for three successive years and a majority of firms earning returns on assets of two percent or less for two years did not impair their goodwill. Again, the results support the contention studied here, that the Statement of Financial Accounting Standards Number 142 provides an opportunity for management to manipulate reported earnings.

Lastly, it would be interesting to expand the period covered with a larger sample so that the behavior of management in situations where companies have high returns on assets after periods of sub-par performance. Should such be undertaken, clearly additional accounting measures could be employed.

\section{REFERENCES}

1. American Institute of Certified Public Accountants (AICPA), 1970. Intangible Assets. Accounting Principles Board Opinion 17, New York, NY: AICPA.

2. Financial Accounting Standards Board (FASB), 2001. Goodwill and other intangible assets, Statement of Financial Accounting Standard No. 142. Hartford, CT: FASB.

3. McCarthy, M. G. and D. K. Schneider, 1995, Market perception of goodwill: Some empirical evidence, Accounting and Business Research 26 (1); 69-81.

4. McKee, Thomas E., 2005. Earnings management: An executive perspective. Thomson/ South Western, 5191 Natorp Blvd, Mason, Ohio, pp.23.

5. Massoud, Marc, F. and Cecily A. Raiborn, 2003. Accounting for goodwill: Are we better off. Review of Business, Spring Vol. 24 No. 2, pp, 26-32.

6. Steven L. Henning, Barry L. Lewis and Wayne H. Shaw. 2000, Valuation of the components of purchased goodwill, Journal of Accounting Research, Vol. 38, No. 2 autumn.

7. Wines, G., and C. Ferguson, 1993. An empirical investigation of accounting methods for goodwill and identifiable intangible assets; 1985 to 1989, ABACUS 29(1); 90-105. 
NOTES 